\title{
Chemical composition and biological activity of Allium sativum essential oils against Callosobruchus maculatus
}

\author{
Lalla fatima Douiri ${ }^{1}$, Ahmed Boughdad ${ }^{2}$, Omar Assobhei ${ }^{3}$, \\ Mohieddine Moumni ${ }^{4}$ \\ ${ }^{1,4}$ (Department of Biology Sciences Faculty, / Moulay Ismail University, B.P. 11201, Meknès, Morocco) \\ ${ }^{2}$ (Department of Plant Protection and Environment / National school of Agriculture, B.P. S/40 50000 Meknès \\ Morocco) \\ ${ }_{3}^{3}$ (Chouaib Doukkali University, Faculty of Sciences BP 20, 24000 El Jadida Morocco)
}

\begin{abstract}
In order to search for alternative control methods to synthetic pesticides, the potential of essential oils from Allium sativum (L.) (Alliaceae); was evaluated as fumigants against Callosobruchus maculatus (fab.) (Coleoptera: Bruchidae), a pest that attacks pulses during storage. Chickpea seeds were infested with 10 pairs of newly emerged weevils and, fumigated with $0,1,2,3$, or $4 \mu$ l of essential oils of garlic/l of air. The essential oils of garlic were analyzed by GC-MS. The major components were trisulfide, di-2-propenyl and diallyl disulfide. Garlic essential oils significantly affected bruchid's fecundity (treated $=17-59<$ control $=288-310$ ), longevity (treated $=1-3<$ control $=2-13$ days), fertility (treated $=0-62.96<$ controls $=89.03-93.40 \%$ ) and success rate (treated $=0<$ control $=80-90 \%$ ). The $L C_{50}$ and $L C_{99}(24 \mathrm{~h})$ were respectively 2.5 and $23.3 \mu \mathrm{l} / \mathrm{l}$ of air for females and 2.56 and $46.07 \mu \mathrm{l} / \mathrm{l}$ for

The fumigation of stored products against insect pests with garlic essential oils could be considered as an integrated pest management (IPM) tactic without risk for consumers and the environment.
\end{abstract}

Keywords: Allium sativum; Callosobruchus maculatus; Essential oils; Fumigation; Stored products

\section{Introduction}

In Morocco, chickpeas, Cicer arietinum (L.), cultivation is one of the most important legume crops. They are an important source of protein. Unfortunately, the leguminous seeds specially Cicer arietinum (L.) are attacked during storage mainly by the multivoltine bruchids (weevils) inducing Callosobruchus maculatus. This species can destroy a whole stock [1].

The most common means in food pest control are use of synthetic insecticides whose effects on the environment can cause water, soil, and atmospheric pollution as well as intoxication of the fauna and flora. The health effects can result in cancer or neurological, dermatological and reproductive functions as well as the immune and endocrine systems [2]. More than 20000 accidental deaths and 3Million cases of pesticide poisoning are reported in the world every year [3]. Moreover, in the last few decades, attention drawn to the secondary effects of pesticides has profoundly modified the perception regarding these substances. Considered almost miraculous products in the past, they are now seen by some as harmful products to be excluded or a necessary evil at best [4]. Some cytogenetic studies revealed the existence of genetic perturbations related to cancer amongst users of these pesticides. Globally, those studies have shown an elevation in the frequency of damage to the DNA [5], [6], [7] chromosomal deviations (E.G, broken, translocation) [8], [9], [10], [11], existence of micronuclei [12], [13] [14], DNA adducts [15] in peripheral blood lymphocytes and increase in the 8- $\mathrm{OH}-\mathrm{dG}$ oxidized bases in the plasma [11].

Alliaceae are plants of various biological properties. Garlic is known for its positive effects on health, particularly the prevention of cardiovascular diseases and certain digestive cancers. The compounds suspected to be involved are sulfide compounds.

These molecules also possess some insecticidal, fungicidal, acaricidal, nematicidal, and bactericidal properties [16], Sulfide compounds such as diallyl disulfide (DADS) and allicin (DATi) in garlic are responsible for the phytosanitary potential of Alliums [17]. The essential oils of garlic are used as a barrier to prolong the life processed foods Robson and Ofuya [18] found that crushed fresh bulbs of A. sativum and A. cepa L. present a biocidal effect on C. maculatus. Moreover Rajendran and Srianjini [19] showed that essential oils from more than 75 plants had been evaluated for their smoke toxicity insects in stored products. David et al [20] demonstrated that eugenol, the essential compound of Eugena caryophyllatta exerts a special effect on octopamin receptors and presents insecticidal properties. The essential oils action mechanisms against insects 
are more and more understood. Recent works pointed out that monoterpenes inhibited the cholinesterase; sulfur compounds acted on potassium channels cockroach and have no cholinergic effect [21]. Essential oils are nowadays known as neurotoxins with acute effects interfering with the arthropods' octopaminergic transmitters.

In this study we put forth a presentation of the composition of garlic essential oils and their semiochemical effectss on different biological and physiological parameters of C. maculatus.

\section{Material and Methods}

\subsection{Material}

\subsubsection{Garlic: Allium sativum L.}

The garlic used is red and was purchased in the wholesale market of Meknes.

\subsubsection{Strain of Callosobruchus maculatus}

The strain of Indian bruchid, C. maculatus (Coleoptera, Bruchidae) was acquired at the wholesale market of Meknes (Morocco). It was raised in the laboratory on chickpea seeds, C. Arietinum, in Petri dishes (culture plates), inside glass desiccators with a capacity of 4.51 in $20-30^{\circ} \mathrm{C}, 65 \% \pm 5 \%$ of relative humidity and in daylight for several successive generations.

\subsection{Extraction and analysis of Essential oils}

Extraction of the essential oils from $100 \mathrm{~g}$ of fresh cloves of garlic $(32.27 \mathrm{~g} \pm 2.5$ of dry weight $)$ was performed with a Clevenger hydrodistiller. The hydrodistillation lasted 3hours at $120^{\circ} \mathrm{C}$. The essential oils were dehydrated with anhydrous sodium sulphate weighed and stored in a refrigerator at $4^{\circ} \mathrm{C}$ until use.

The chemical analysis of essential oils was done with a GC ULTRA gas chromatograph outfitted with a column of type VB5 (50\% phenyl, 95\% methylpolisyloxane) $(30 \mathrm{~m}, 0.5 \mathrm{~mm}, 25 \mathrm{um}$ ) and coupled to a mass spectrometer type a PolarisQ with ion trap (EI $70 \mathrm{eV}, 10-00 \mathrm{uma}$ ). The scanning range was from 10 to $300 \mathrm{~m} / \mathrm{z}$. The oven temperature ranged from $50^{\circ} \mathrm{C}$ to $250^{\circ} \mathrm{C}$ at a rate of $5^{\circ} \mathrm{C} / \mathrm{min}$ and $250^{\circ} \mathrm{C}$ to $300^{\circ} \mathrm{C}$. Helium was used as carrier gas at $1 \mathrm{ml} / \mathrm{min}$. The injection temperature was $250^{\circ} \mathrm{C}$. $1 \mu \mathrm{l}$ of essential oils diluted to $1 / 10$ in hexane was injected manually in split mode. The identification of constituents of essential oils was performed using the database NIST MS Search.

\subsection{Biological tests}

In Petri dishes ( $9 \mathrm{~cm}$ of diameter) 50 seeds of chickpea (about $24 \mathrm{~g}$ ) were taken randomly and exposed to 10 couples of de $C$. maculatus. With a micropipette, $1 \mu 1,2 \mu l, 3 \mu l$ and $4 \mu l$ of essential oils of A. sativum were placed in an isolated manner in a sear watch glass. Each concentration was put inside 4.51 glass desiccators with three Petri's dishes each containing 50 seeds of chickpea infected with 10 weevil couples. In parallel 50 untreated chickpea seeds were also presented to 10 couples and used as control in other desiccators. For every tested concentration 3 repetitions were done. During the experimentation the desiccators were kept tightly closed.

After 24 hours, adult's mortality was recorded daily by sex until the death of all adults, whereas the numbers of eggs that hatched or didn't hatch were counted 10 days after. Then, right at the beginning of the emergence (26 days after the eggs were laid), the number of emerged adults was counted every day until the end of the emergence. The parameters measured were longevity, fecundity, fertility of eggs $=(($ Number of eggs hatched / Number of eggs laid $* 100)$, embryo mortality rate $=(($ Number of eggs laid - Number of eggs hatched)/ laying number of eggs laid $* 100)$, rate of successful birth $=(($ number of adults emerged /(Number of eggs laid $\left.)^{* 100}\right)$; mortality rate within the seeds $=(($ Number of eggs hatched - Number of adults emerged $) /$ Number of eggs hatched)*100.

\subsection{Theory/calculation (Data analysis)}

In order to detect significant eventual differences between the effects of garlic essential oils on C.maculatus, analysis of variance followed by Scheffé's test at 5\% were conducted. The statistical analyses were done using raw data, for quantitative variables (Longevity, fecundity) and using data normalized with $\operatorname{Arcsin}($ square $\operatorname{root}(\%)$ ) for proportions (fertility, success rate). The program used was Excel version 2010.

The lethal concentrations for $50 \%\left(\mathrm{LC}_{50}\right)$ or $99 \%\left(\mathrm{LC}_{99}\right)$ of individuals exposed to different concentrations tested, the slopes of a straight lines and confidence intervals were determined by probit method [22] (Finney, 1971) , using software «EPA Probit analysis program Version 1.5»; they were expressed by $\mu$ l of garlic essential oil / 1 of air. Mortality was adjusted using Abbott's formula [23]. Lethal times 50\% or 99\% of adults, 
exposed to different concentrations studied, were calculated with straight regression lines between the concentrations and the insect's duration of exposure.

\subsection{Chemical composition of garlic essential oils}

\section{Results}

The yield obtained in essential oils was $0.32 \% \pm 0.2$ of garlic fresh weight. Garlic essential oils were composed of a lot of compounds, appeared between 5.61 and $40.58 \mathrm{~min}$, its relative abundance, varied to 0.66 to $46.52 \%$. With peak area times (Table I). The principal groups of components are sulfur componunds, represented mainly by, trisulfides (57.4\%) and disulfides (23.16). Indeed, the chemical compounds corresponding to the major components of garlic essential oils, those relative abundance exceeds $5 \%$ of the peak areas are trisulfide, di-2-propenyl (46.52\%); disulfide, di-2-propenyl (16.02\%); trisulfide, methyl 2di-2propenyl (10.88\%) and diallyl disulide (7.15\%) (Table1).

TABLE 1: Compounds of garlic essential oils

\begin{tabular}{|c|c|c|c|c|}
\hline $\begin{array}{c}\text { Retention } \\
\text { Times (min) }\end{array}$ & CAS & Compounds & Formula & Holder (\%) \\
\hline 5.61 & $501-23-7$ & 1,3 dithiane & $\mathrm{C}_{4} \mathrm{H}_{8} \mathrm{~S}_{2}$ & 2.03 \\
\hline 9.69 & 2 2179-57-9 & Disulfide, di-2-propenyl & $\mathrm{C}_{6} \mathrm{H}_{10} \mathrm{~S}_{2}$ & 14.30 \\
\hline 10.27 & $592-88-1$ & 1-Propene,3,3'-thiobis- & $\mathrm{C}_{6} \mathrm{H}_{10} \mathrm{~S}$ & 3.93 \\
\hline 11.30 & $34135-85-8$ & Trisulfide,methyl 2-propenyl & $\mathrm{C}_{4} \mathrm{H}_{8} \mathrm{~S}_{3}$ & 10.88 \\
\hline 12.64 & $62488-53-3$ & 3-vinyl-[4H]-1,3-dithiin- & $\mathrm{C}_{6} \mathrm{H}_{8} \mathrm{~S}_{2}$ & 1.01 \\
\hline 13.31 & $80028-57-5$ & 2-vinyl-[4H]-1,3-dithiin- & $\mathrm{C}_{6} \mathrm{H}_{8} \mathrm{~S}_{2}$ & 1.64 \\
\hline 15.73 & $2050-87-5$ & \multirow{2}{*}{$\begin{array}{l}\text { Trisulfide, di-2-propenyl } \\
\text { 3-vinyl-[4H]-1,2 dithiin1-chloro-4-(1- } \\
\text { ethoxy)-2-methylbut-2-ene }\end{array}$} & $\mathrm{C}_{6} \mathrm{H}_{10} \mathrm{~S} 3$ & 46.52 \\
\hline 16.41 & $62488-53-3-3$ & & $\mathrm{C}_{6} \mathrm{H}_{8} \mathrm{~S}_{2}$ & 1.52 \\
\hline 17.80 & $2179-58-0$ & Disulfide,-methyl 2-propenyl & $\mathrm{C}_{4} \mathrm{H}_{8} \mathrm{~S}_{2}$ & 1.71 \\
\hline 21.74 & $2179-57-9$ & Diallyl disulfide & $\mathrm{C}_{6} \mathrm{H}_{10} \mathrm{~S}_{2}$ & $7 / 15$ \\
\hline 24.53 & $62488-53-3$ & 3 -vinyl-[4H]-1,2 dithiin & $\mathrm{C}_{6} \mathrm{H}_{8} \mathrm{~S}_{2}$ & 2.76 \\
\hline 26.70 & 89534-73-6 & Sulfide, methyl1-methyl-2-butenyl & $\mathrm{C}_{8} \mathrm{H}_{17} \mathrm{~S}_{3}$ & 0.66 \\
\hline \multirow[t]{5}{*}{40.58} & $999-06-4$ & Octane, 4 brom- & $\mathrm{C}_{8} \mathrm{H}_{17} \mathrm{Br}$ & 4.16 \\
\hline & & \multicolumn{2}{|c|}{ Disulfides } & 23.16 \\
\hline & & \multicolumn{2}{|c|}{ Trisulfides } & 57.4 \\
\hline & & \multicolumn{2}{|c|}{ Others } & 17.71 \\
\hline & & \multicolumn{2}{|c|}{ Total } & 98.27 \\
\hline
\end{tabular}

\subsection{Effects of garlic essential oil on Callosobruchus maculatus}

3.2.1 Effects on longevity

Male and female adults of $C$. maculatus in contact the different concentrations of garlic essential oils lived only 1 to 3days following treatment, while longevity of control male and female adults varied from 1 to 13days (Fig 1). Garlic essential oils thus affesct the weevils' longevity very significantly.
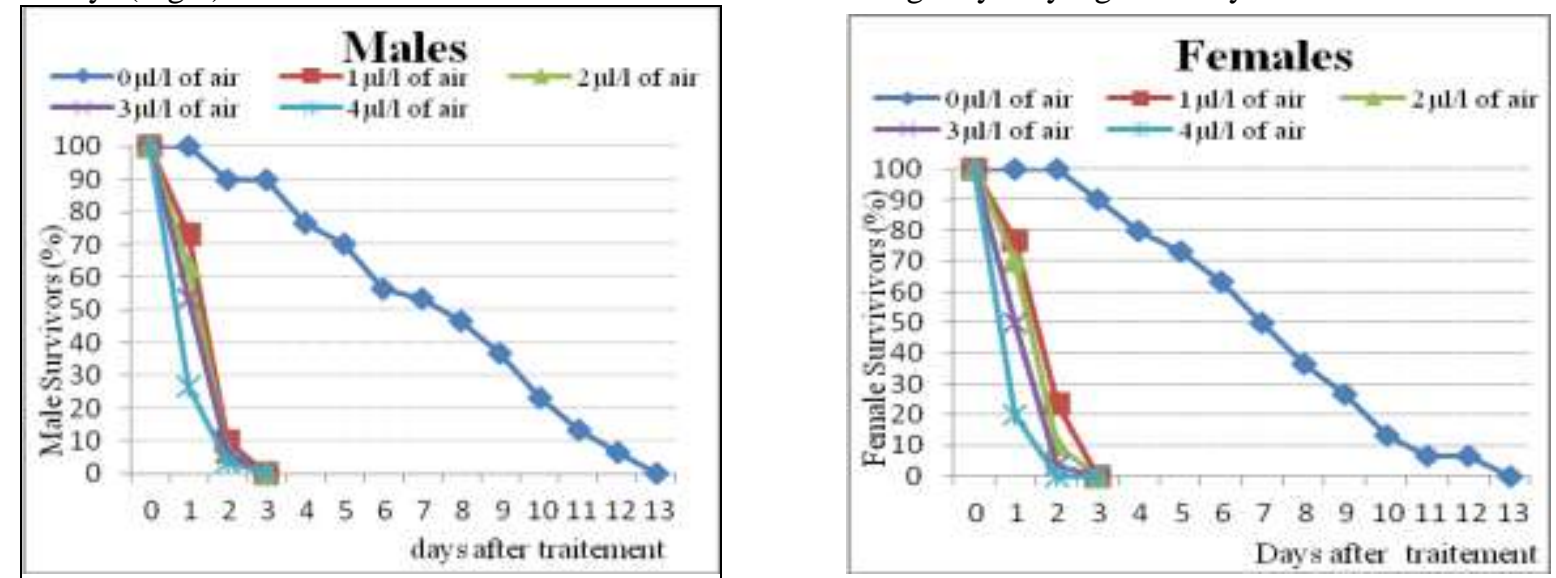

Figure 1: Survival curves of adult Callosobruchus maculatus fumigated with Allium sativum essential oils).

Somewhere, lethal times to $50 \%$ and $99 \%$ of adults fumigated with garlic essential oils varied approximately between the $1^{\text {st }}$ and the $13^{\text {th }}$ days depending on the sex and the concentration considered. They were negatively correlated with essential oils concentrations (Table II). 
Table II: (Lethal times of adult Callosobruchus maculatus fumigated with Allium sativum essential oils)

\begin{tabular}{lrrrcc}
\hline Sex & Concentration $(\mu \mathrm{l} / \mathrm{l}$ air $)$ & $\mathrm{LT}_{50}$ & $\mathrm{r}$ & $\mathrm{LT}_{99}$ & $\mathrm{r}$ \\
\hline \multirow{4}{*}{ Males } & 0 & 7,05 & & 12,98 & \\
& 1 & 1,46 & & 3,26 & \\
& 2 & 1,29 & $-0,75$ & 2,66 & $-0,70$ \\
& 3 & 1,29 & & 3,22 & \\
\multirow{3}{*}{ Females } & 4 & 0,94 & & 3,10 & \\
& 0 & 7,15 & & 12,77 & \\
& 1 & 1,64 & & 3,41 & \\
& 2 & 1,48 & $-0,78$ & 3,30 & $-0,73$ \\
& 3 & 1,23 & & 3,19 & \\
& 4 & 0,82 & & 3,05 & \\
\hline
\end{tabular}

Garlic essential oils exert a strong toxicity on bruchid. In fact after 24 hours of exposure of adult bruchids to the different concentrations tested, $\mathrm{LC}_{50}$ and $\mathrm{LC}_{99}$ were 2.50 and $23.30 \mu \mathrm{l} / \mathrm{l}$ of air for females and 2.56 and 46.07 $\mu \mathrm{l} / \mathrm{l}$ of air for males, mortality of $C$. maculatus increased linearly with the concentration of oils used (Table III).

Table III: (Toxicity parameters of garlic essential oils on adult of Callosobruchus maculatus)

\begin{tabular}{lcccc}
\hline Adults & $\begin{array}{c}\text { Laying of eggs } \pm \\
\text { standard error }\end{array}$ & $\begin{array}{c}(\mathrm{Chi} 2) \chi^{2}<\chi^{2}(2 ; \\
0.05)=5.991\end{array}$ & $\begin{array}{c}\mathrm{LC}_{50}[\mathrm{CI}](\mu \mathrm{l} / \mathrm{l} \text { of } \\
\text { air })\end{array}$ & $\mathrm{LC}_{99}[\mathrm{CI}](\mu \mathrm{l} / 1$ of air $)$ \\
\hline Females $(\mathrm{N}=120)$ & $2.40 \pm 0.57$ & 4.76 & 2.50 & $23.30[10.97 ; 174.66]$ \\
\hline Males $(\mathrm{N}=120)$ & $1.85 \pm 0.54$ & 2.66 & $\begin{array}{c}2.56 \\
{[1.96 ; 3.30]}\end{array}$ & $\begin{array}{c}46.07 \\
{[15.05 ; 687.28]}\end{array}$ \\
\hline
\end{tabular}

*: Confidence interval

\subsubsection{Effects on fecundity, fertility, Mortality of eggs, mortality in the seed and the emergence succees}

The fecundity of $C$. maculates on seeds of chickpea, fumigated with the different concentrations of garlic essential oils, is strongly affected. The number of eggs laid on fumigated seeds is significantly low compared to that observed on untreated seeds $\left(\mathrm{F}=339,17>\mathrm{F}_{(0,05 ; 4-14)}=3,48\right)$. It varies between 17 and 59 eggs/10females in the treated groups according to the concentration considered versus $288-310$ eggs/10 females in the control (fig 2). Decreased fecundity of $C$. maculatus is related to the early death of the females that did not exceed 3 days in the treated groups.

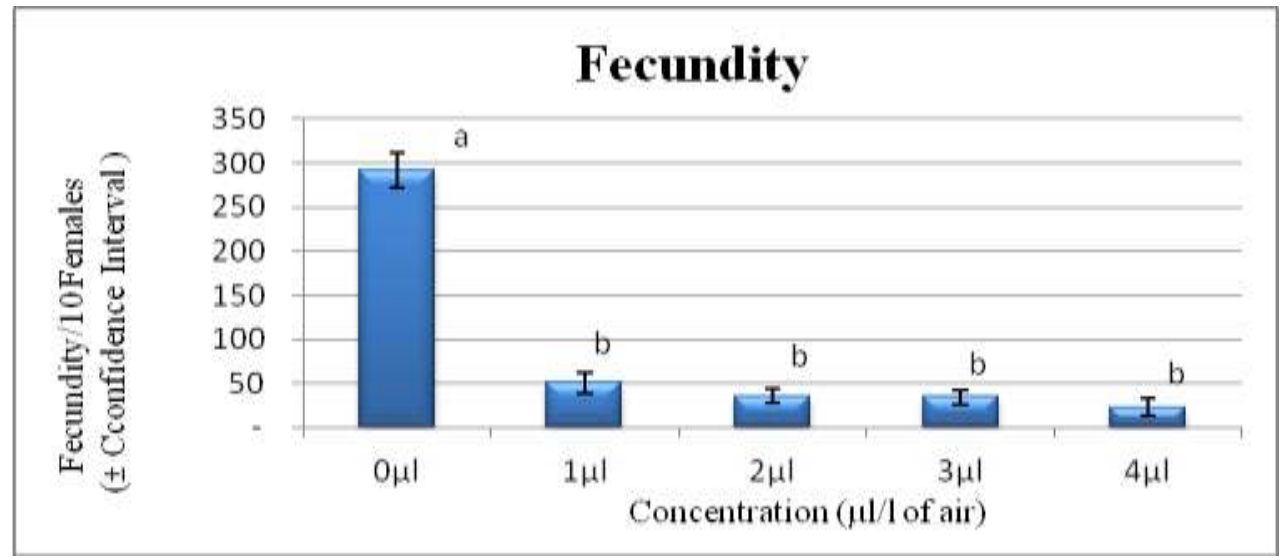

Figure 2: Fecundity of Callosobruchus maculatus on chickpea seeds fumigated with different concentrations of garlic essential oils (bars with the same letter are not statistically different, AV1F followed by Scheffé's test at $5 \%)$.

The fertility of $C$. maculatus eggs laid on seeds fumigated with the garlic essential oils is lower compared to that of the control. Iit varied from 0 to approximately $62,96 \%$ of the eggs laid in the treated groups vs. $89,03-93,40 \%$ in the control lots $\left(f_{\text {calculated }}=178,72>f_{(0,05 ; 4-14)}=3,48\right)$. It is null for the concentration of $4 \mu 1 / 1$ of air (fig 3 ). The garlic essential oils have ovicidal properties. 


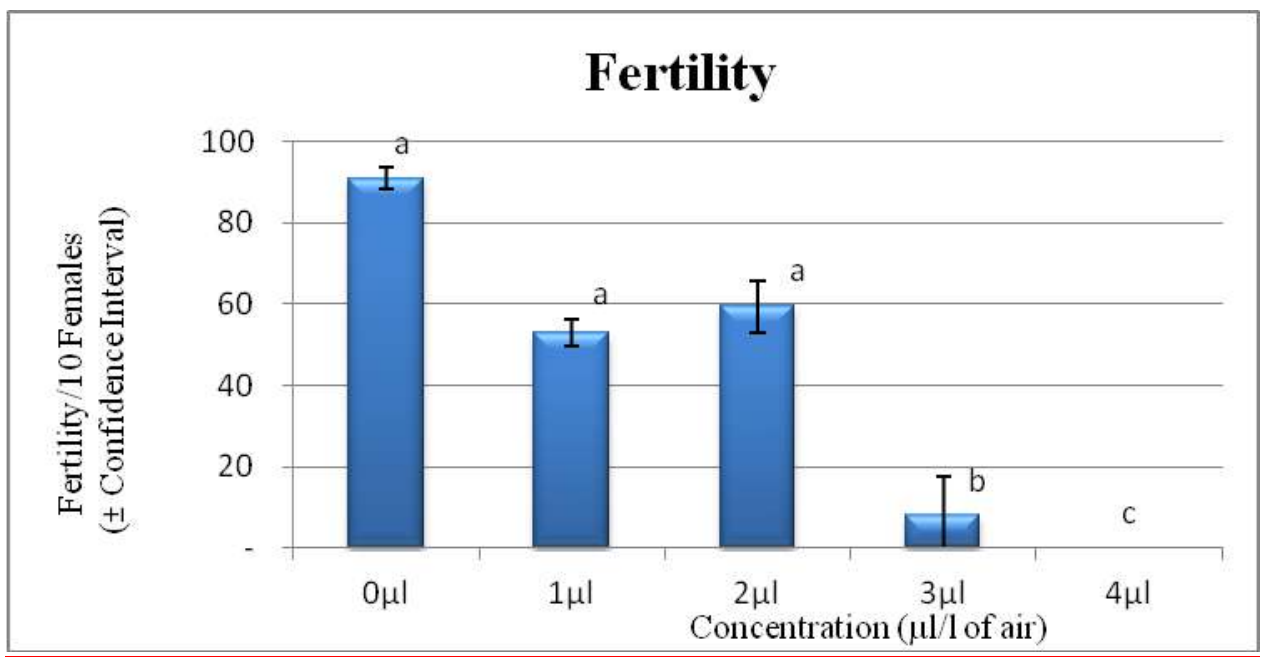

Figure 3: The fertility of Callosobruchus maculatus eggs laid on chickpea seeds fumigated with different concentrations of garlic essential oils (bars with the same letter are not statistically different, AV1F followed by Scheffé's test at $5 \%$.

In this test, the garlic essential oils show to be toxic in larval and nymphal states of the bruchid. The mortality of eggs ranges from to $6.60-10.97 \%$ in the control groups, and reaches $22.22-100 \%$ in the treated lots. As for mortality in seeds, it was high $(100 \%)$ with even the lowest concentration $(1 \mu \mathrm{l})$ compared to only 5.95$21.20 \%$ for the control. No adult emerged out of seeds with the different concentrations, but 671 adults emerged from the control seeds. (Table IV).

Table IV: (Biological parameters of Callosobruchus maculatus fumigated with garlic essential oils)

\begin{tabular}{llcccc}
\hline & \multicolumn{5}{c}{ Concentrations in $\mu \mathrm{l} / \mathrm{l}$ of air } \\
\cline { 2 - 6 } Biological parameters & \multicolumn{1}{c}{0} & 1 & 2 & 3 & 4 \\
\hline Fecundity & $291.67^{\mathrm{a} *} \pm 16.80$ & $50.67^{\mathrm{b}} \pm 10.41$ & $35.33^{\mathrm{bc}} \pm 7.37$ & $34.33^{\mathrm{bc}} \pm 7.64$ & $22.67^{\mathrm{c}} \pm 8.96$ \\
Fertility & $90.90^{\mathrm{a}} \pm 2.26$ & $52.43^{\mathrm{b}} \pm 3.32$ & $59.43^{\mathrm{b}} \pm 5.69$ & $7.99^{\mathrm{C}} \pm 8.85$ & $0^{\mathrm{d}} \pm 0$ \\
Eggs mortality & $9.14^{\mathrm{a}} \pm 2.26$ & $47.15^{\mathrm{b}} \pm 3.32$ & $42.7^{\mathrm{b}} \pm 18.60$ & $92.01^{\mathrm{c}} \pm 8.35$ & $100^{\mathrm{c}} \pm 0$ \\
Descendants & $223.67^{\mathrm{a}} \pm 28.10$ & $0^{\mathrm{b}}$ & $0^{\mathrm{b}}$ & $0^{\mathrm{b}}$ & $0^{\mathrm{b}}$ \\
Emergence & $76.61^{\mathrm{a}} \pm 9.61$ & $0^{\mathrm{b}}$ & $0^{\mathrm{b}}$ & $0^{\mathrm{b}}$ & $0^{\mathrm{b}}$ \\
Mortality in seed & $15.69^{\mathrm{a}} \pm 8.66$ & $100^{\mathrm{b}}$ & $100^{\mathrm{b}}$ & $100^{\mathrm{b}}$ & $100^{\mathrm{b}}$ \\
\hline
\end{tabular}

*: means within the same row with a common superscript do not differ (AV1F followed with Scheffé test at $5 \%)$.

\section{Discussion}

In this study, garlic essential oils content neared $0.32 \% \pm 0.2$ of the clove's fresh weight. The principal chemical components are trisulfide di-2propenyl, disulfide di-2propenyl, trisulfide methyl 2propenyl and diallyl dissulfide. These results are similar to those found by Pyun and Shin [24] in the case of garlic from Beijing. The sulfur components, obtained from cysteine derived precursors, are responsible for the biocidal activity against phytophagous biological agents [16].

Concerning the biocidal effects of garlic essential oils, the fumigation of chickpea seeds with these components against $C$. maculatus has harmufel effects at all stages of the development of the bruchid. These oils are toxic to adults and to pre-imagol stages. They also significantly affected the oviposition potential of the insecs. Similar results were demonstrated on the same bruchid by a Dungum et al. [25], Oparaeke and Bunmi [26], Adedire et al. [27] Ileke et al. [28]. A lot of entomological species are sensitive to sulfuric compounds of Alliaceae [29]. According to Abiodun et al. [30] essential oils of Allium sativum disposed of the potential to protect stored cowpea seeds from damage caused by $C$. maculatus.

Longevity of adult insects is significantly shorter than those in the control experiment. As has been observed by Huignard et al. [31], Ngamo et al [32] and ILeke et al [28]; in agreement with these authors, $\mathrm{LC}_{50}$ and $\mathrm{LC}_{99}$ (24h) are very low.

Thiosulfinates were tested on C. maculates, Sitophilus oryzae, S. granarius, Ephestia kuehniella and Plodia interpunctella. Dimethyl and diallyl thiosulfinates appeared to be more toxic than disulfur to all insects tested. They have a $\mathrm{LC}_{50}(24 \mathrm{~h})$ ranging between 0.02 and $0.25 \mathrm{mg} / \mathrm{l}$. They even showed a higher insecticidal activity than methyl bromide [30]. (Auger et al.2002) founded that DMDS also caused a significant ovocidal 
activity to insects and mites. [33]. Ofuya et al. [34]; proved that fumigation of pods with crushed cloves of Allium sativum and A. cepa, showed a toxic effect to C.maculatus. The essential oils of Thymus vulgaris, Santolinachamae cyparissus and Anagyris foetida posses an insecticidal effect against C.chinensis (chickpea weevil) [35].

Garlic's essential oils also reduced fecundity and/or annulled fertility and the success rates of the bruchids. Similar results were observed by [32] Ho [36] with the same oils against Tribolium castaneum and on Sitophilus zeamais (Ileke et al. [28]. Garlic essential oils inhibit bruchid's locomotion, which affects its reproductive activity. This effect was reported by many authors (Okonkwo and Okoye, [37], Adedire[27], Akinkurolere et al [38]. Therefore these compounds affect the growth, moulting, fecundity, and the development of insects and acarids [33]. The insecticidal essential oils are highly active on insects without altering the germination ability of treaded seeds (Keita et al) [39]. Howeverm they have a marketing problem (Isman) [40].

\section{Conclusions}

The essential oils of garlic can be used as an alternative to synthetic pesticides, which allows better managing pests resistant to synthetic products and mitigating their adverse effects on the health of users and consumers. In fact, the essential oils are produced from renewable, botanical, biodegradable products. They act at low doses, they are economical and their environmental impact is low and often undetectable.

Before considering the integration of essential oils of garlic in the management of stored products, it would be advisable to extend these tests to other harmful agents witch allows considering the use of essential oils of garlic as an alternative to fumigation by methyl bromide, which is to be withdrawn from agricultural use in Morocco in 2015. It would also be interesting to determine the exact compounds responsible for the biocidal activity and their mechanisms of action on the targets as well as their effects on consumers and subsidiaries.

\section{Acknowledgements}

I want to thank the personal of the National Centre for Scientific and Technical Research (CNRST) in Rabat who performed the analysis of garlic essential oils and the professor Hafid Alaoui for correcting the english manuscript.

\section{References}

[1] A. Boughdad Ravageurs des légumineuses alimentaires au Maroc In : Le Secteur des légumineuses alimentaires au Maroc MARA/DPV/GTZ (eds). Actes de l'Institut IAV Hassan II; Rabat 1992. pp : 315-338.

[2] Pasp 2005; Programme africain relatif aux stocks de pesticides obsoletes), Maroc (agriculture.gouv.fr).

[3] Pan africa 2003, www.pan-uk.org/.../Morocco

[4] R. Calvet., E. Barriuso, P. Benoit, C. Bedos, M-P. Charnay \& Y. Coquet Les pesticides dans le sol. Conséquences agronomiques et environnementales. Editions France Agricoles, Paris, 2005, 637 p.

[5] P. Lebailly, C. Vigreux, C. Lechevrel, D. Ledemeney, Godard T., Sichel F., J.Y. LeTalaer, M.Henry-Amar, \& P. Gauduchon , DNA damage in mononuclear leukocytes of farmers measured using the alkaline comet assay: modifications of DNA damage levels after a one-day field spraying period with selected pesticides. Cancer Epidemiol Biomarkers Prev. 7(10), 1998, 929-940.

[6] V. Garaj-Vrhovac \& D. Zeljezic. Evaluation of DNA damage in workers occupationally exposed to pesticides using single-cell gel electrophoresis (SCGE) assay,Pesticide genotoxicity revealed by comet assay. Mutat Res. 469(2), 2000, $279-285$.

[7] M-F. Simoniello, E- C.Kleinsorge, J. A. Scagnetti, R-A.Grigolato, G- L Poletta, \& M-A. Carballo , DNA damage in workers occupationally exposed to pesticide mixtures and mixtures. J Appl Toxicol. Nov; 28(8), 2008, 957-65.

[8] B. F. Lander, L. E. Knudsen, M. O. Gamborg, H. Jarventaus, \& H. Norppa, Chromosome aberrations in pesticide-exposed greenhouse workers. Scand J Work Environ Health. 26(5), 2000. 436-442.

[9] S. Roulland, P. Lebailly, Y. Lecluse, M. Briand, D Pottier \& P.Gauduchon, Characterization of the (14; 18) BCL2-IGH translocation in farmers occupationally exposed to pesticides. Cancer Res. 64(6), 2004, 2264-2269.

[10] N. Sailaja, M. Chandrasekhar, P-V. Rekhadevi , M. Mahboob, M-F. Rahman, S B.Vuyyuri, K. Danadevi, S-A. Hussain, and P. Grover. Genotoxic evaluation of workers employed in pesticide production. Mutat Res. 609(1), 2006, 74-80.

[11] J- F. Muniz, L. Mc Cauley, J. Scherer, M. Lasarev, M. Koshy, Y-W. Kow, V.Nazar-Stewart, and G. E. Kisby, Biomarkers of oxidative stress and DNA damage in agricultural workers: a pilot study. Toxicol Appl Pharmacol. 227(1), 2008, 97-107.

[12] S. Gomez-Arroyo, Y. Diaz-Sanchez, M. A.Meneses-Perez, R. Villalobos-Pietrini, , and J. De Leon-Rodriguez,. Cytogenetic biomonitoring in a Mexican floriculture worker group exposed to pesticides. Mutat Res. 466(1), $2000,117124$.

[13] C. Bolognesi, E. Perrone, \& E. Landini, Micronucleus monitoring of a floriculturist population from western Liguria, Italy. Mutagenesis. 17(5), 2002, 391-397.

[14] C. Costa, J- P.Teixeira, S. Silva, J. Roma-Torres, P. Coelho, J. Gaspar, M. Alves, B. Laffon, J.Rueff \& O. Mayan Cytogenetic and molecular biomonitoring of Portuguese population exposed to pesticides. Mutagenesis. 21(5), 2006, 343-350.

[15] J. Le Goff, V.Andre, P. Lebailly, D ,.Pottier, F., Perin, O., Perin, and P,Gauduchon, Seasonal variations of DNA-adduct patterns in open field farmers handling pesticides. Mutat Res. 587(1-2), 2005, 90-102.

[16] J. Auger \& E. Thibout. Substances soufrées des Allium et des crucifères et leurs potentialités phytosanitaires. In : Biopesticides d'origine végétale, Ed Tec et Doc, 2002, 77-95.

[17] L. Arnaut, L. André, S. Diwo-Allain, J. Auger \& F. Vey. Propriétés pesticides des alliacées : Biodésinfection des sols maraîchers au moyen d'oignon et poireau. Phytoma- la défense des végétaux ; $58,2005,40-43$.

[18] A. Robson, R.,Wilson, C. Garcia de Leqniw. Mussels flexing their muscles: a new method for quantifying bivalve behaviour. Marine Biology, 2007, 151:1195-1204. Doi: 10.1007/s00227-006-0566-z. CrossRef

[19] S. Rajendran, and V. Srianjini, Plant products as fumigants for stored product insects control. J. Stored Prod. Res., 44: 2008, 126-135. 
[20] J.P. David, C.Srode, J.Vontas, D.Nikou, , A.Vaughan, P.M. Pignatelli, C.Louis, , J.Hemingway, H.Ranson, The Anopheles gambiae detoxifi cation chip: a highly specifi c microarray to study metabolic-based insecticide resistance in malaria vectors. Proc. Natl. Acad. Sci. USA 2005,102, 4080-4084.

[21] S. Dugravot Analyse de la réponse d'insectes spécialistes et non-spécialistes à un composé soufré. Diplôme d'études approfondies, Université de Tours, 2000, 25 p.

[22] D.J. Finney. Probit analysis. $3^{\text {th }}$ ed Cambridge University Press. IBSN 0- 521080421 X, 1971, 333p.

[23] W. Abbott. A method of computing the effectiveness of an insecticide.J. Econ. Entomol. 18, 1925, $265-267$.

[24] M-S. Pyun \& S. Shin,.Antifungal effects of the volatile oils fromAllium plants against Trihophyton species and synergism of the oils with ketoconazole, Pytomedecine, 13, 2005, 394-400p.

[25] S.M. Dungum, M.C. Dike, S.A. Adebitan, and J.A. Ogidi,. Efficacy of plant materials in the control of field pests of cowpea. Nigerian Journal of Entomology, 22, 2005, 46-53.

[26] A. M. Oparaeke,. \& J. O. Bunmi, Bioactivity of two powdered spices (Piper guineense Honn \& Schum and Xylopia Aethiopica (Dunal) A. Richard) as home made insecticides against Callosobruchus subinnotatus (Pic.) on stored Barbara groundnut. Agricultura Tropica and Subtropica, 39(2): 2006, 132-134.

[27] C-O. Adedire, O.Obembe, R-O. Akinkurolele \& O. Oduleye. Response of Callosobruchus maculatus (Coleoptera: Chysomelidae: Bruchidae) to extracts of cashew kernels. Journal of Plant Diseases and Protection, 118(2), 2011, 75-79

[28] K.D. Ileke,O.F. Olotuah, A. Adekunle \& A.Akungba. Bioactivity of Anacardium occidentale (L) and Allium sativum (L) powders and Oils Extracts against Cowpea Bruchid, Callosobruchus maculatus (Fab.) [Coleoptera: Chrysomelidae]. Inernational Journal of Biology. Vol 4, N¹, 2012, 96-103p.

[29] J. Auger, S. Dugravot, A.Naudin, A.Abo-Ghalia, D. Pierre \& E.Thibout. Utilisation des composés allélochimiques des Allium en tant qu'insecticides, IOBC wprs Bulletin, 259, 2002, 295-308

[30] A.D. Abiodun Bioactivity of Powder and Extracts from Garlic, Allium sativum L. (Alliaceae) and Spring Onion, Allium fistulosum L. (Alliaceae) against Callosobruchus maculatus F. (Coleoptera: Bruchidae) on Cowpea, Vigna unguiculata (L.) Walp (Leguminosae) Seeds. Hindawi Publishing , Psyche. Volume 2010, Article ID 958348, 5 pages doi:10.1155/2010/958348.A-F.

[31] J. Huignard, S. Dugravot, K-G. Ketoch, E Thibout \& A-I. Glitho.Utilisation de composés secondaires des végétaux pour la protection des graines d'une légumineuse, le niébé. Conséquences sur les insectes ravageurs et leurs parasitoïdes. In: Biopesticides d'origine végétale, eds, Regnault-Roger. C.,Philogène.B-J-R \& Vincent C. Lavoisir, Tech \& Doc. (Paris 2002), 133-149p.

[32] T-S-L. Ngamo, I. Ngatanko, M-B. Ngassoum, P-M. Mapongmestsem \& T: Hance. Persistence of insecticidal activities of crude essential oils of three aromatic plants towards four major stored product insect pests, African Journal of Agricultural Research 2, 4, 2007, 173-177p

[33] S. Dugravot, A.Sanon, E. Thibout \& J. Huignard. Susceptibility of Callosobruchus maculatus and its parasitoid Dinarmus basalisto two sulphur containing compounds. Consequences on biological control. Environ. Entomol. 31: 2002, 550-557p.

[34] T-I. Ofuya, O-F. Olotuah, and.O-J. Ogunsola. Fumigant toxicity of crushed bulbs of two Allium to Callosobruchus maculatus (Fabricius) (coleoptera: bruchidae). Species chilean journal of agricultural research 70(3): 2010, 510-514p.

[35] M-A Righi-Assia., Khelil., F Medjdoub-Bensaad. \& K.Righi. Efficacy of oils and powders of some medicinal plants in biological control of the pea weevil C.chinensis L. African Journal of Agricultural Research 5(12), 2010, 1474-1481p.

[36] S.H. Ho, L. Koh, Y. MA, Y. Huang \& K.Y. Sim. The oil of garlic, Allium sativum L. (Liliaceae), as a potential grain protectant against Tribolium casteneum (Hebst) and Stipholus zeamais Motsch. Postharvest Biol. Technol., 9, 1996, 41-48p.

[37] EU. Okonkwo, WI. Okoye. The efficacity of four seed powders and the essential oils as protectants of cowpea and maize grains against infestation by Callosobruchus maculatus (Fabricius) (Coleoptera: Bruchidae) and Sitophilus zeamais (Motschulsky) (Coleoptera: Curculionidae) in Nigeria. Int. J. Pest Manage. 42 (3), 1996, p. 143-146.

[38] RO. Akinkurolele, CO. Adedire, OO. Odeyemi . Laboratory evaluation of the toxic properties of forest anchomanes, Anhomanes difformis, against pulse beetle, Callosobruchus maculatus (Coleoptera: Bruchidae). Insect Sci., 13: 2006,25-29

[39] S.M. Kéita, C. Vincent, J-P. Schmit, J.T. Arnason \& A. Bélanger., Efficacy of essential oil of Ocimum basilicum L. and O. gratissimum L. applied as an insecticidal fumigant and powder to control Callosobruchus maculatus (Fab.) (Coleoptera: Bruchidae). Journal of Stored Product research, 37, 2001, 339-349p.

[40] M-B. Isman. Plant essential oils for pest and disease management, Crop Protection, 19, 2000, 603-608p. 